\title{
Kajian Indikator Daya Tampung Lingkungan Binaan dan Sosial di Jawa Timur
}

\author{
Eko Budi Santoso ${ }^{1}$ \\ Ema Umilia ${ }^{2}$ \\ ${ }^{1}$ Urban and Regional Planning Department, Institut Teknologi Sepuluh Nopember, Indonesia \\ Email : eko_budi@urplan.its.ac.id
}

\begin{abstract}
ABSTRAK
Pertumbuhan ekonomi Provinsi Jawa Timur semakin memicu performa pembangunan fisik. Disisi lain, terjadi degradasi dan permasalahan terkait lingkungan di sisi internal maupun ekstrenal Provinsi Jawa Timur. Oleh karena itu, adanya kajian indikator daya tampung lingkungan binaan dan sosial ini dapat dijadikan masukan untuk pembangunan Jawa Timur yang lebih berkelanjutan. Metode yang digunakan adalah metode analisa deskriptif kualitatif yang dilanjut dengan analisa delphi. Hasil dari analisa delphi dalam penentuan indikator daya tampung lingkungan binaan di Jawa Timur didapatkan kesepakatan bahwa indikator yang dapat mengukurnya adalah indikator ketersediaan lahan, ketersediaan sumberdaya air, dan aspek kualitas lingkungan. Sedangkan, indikator dalam penentuan daya dukung lingkungan sosial adalah indikator gaya hidup dan tingkat konsumsi penduduk.
\end{abstract}

Kata Kunci : Daya Tampung Lingkungan Binaan, Daya Tampung Lingkungan Sosial 


\section{PENDAHULUAN}

Jawa Timur sebagai salah satu provinsi dengan luas mencapai kurang lebih 4.779.975 Ha dan terbagi atas 29 wilayah kabupaten dan 9 kota. Pertumbuhan perekonomian di Provinsi Jawa Timur yang mengalami peningkatan pada beberapa tahun ini menunjukkan bahwa performa kinerja pembangunan fisik dan perekonomian semakin menggeliat. Di sisi lain, kegiatan dari pembangunan dan pengembangan wilayah yang semakin intens masih belum mempertimbangkan prinsip pembangunan yang berkelanjutan (sustainable development). Sementara perkembangan penduduk beserta kebutuhannya akan akses terhadap sumber daya yang semakin meningkat, kondisi lingkungan semakin menurun yang ditunjukaan dengan fenomena degradasi dan penurunan kuantitas dan kualitas sumber daya alam dan sarana pendukung yang menjadi kebutuhan penduduk yang semakin menipis dikarekanakan keberadaannya. yang terbatas. Akibatnya terjadi beberapa permasalahan yang dikemukakan sebagai isu eksternal Provinsi Jawa Timur, yaitu kenaikan rasio jumlah penduduk di perkotaan (migrasi), pesatnya perkembangan kota-kota sehingga muncul lebih banyak megacities, isu global warming, restrukturisasi fungsi kota inti yang mengakibatkan perembetan spasial perkotaan sehingga terjadi alih fungsi lahan pertanian dalam skala besar, perkembangan teknologi yang melumerkan batas-batas fisik antar wilayah sehingga kota-kota semakin memiliki dimensi yang luas (globalisasi). Sementara isu internal di wilayah Provinsi Jawa Timur meliputi isu kependudukan, ketersediaan infrastruktur dan fasilitas sosial ekonomi, kesenjangan kosentrasi pembangunan, ketahanan pangan, luapan lumpur Sidoarjo (Lusi), dan meningkatnya alih fungsi hutan lindung dan kerusakan lingkungan yang mengakibatkan ekskalasi bencana.

Adanya degradasi dan permasalahan terkait lingkungan tersebut erat kaitannya dengan adanya kepentingan untuk melakukan kajian terhadap daya dukung dan daya tampung lingkungan sebagai bentuk pelestarian fungsi lingkungan hidup sehingga untuk selanjutnya pemahaman dari hasil daya dukung dan daya tampung lingkungan dapat menjadi masukan dalam pelaksanaan Kajian Lingkungan Hidup dapat dilakukan pencegahan dan pengelolaan terhadap lingkungan sebagai salah satu tindakan dalam penataan ruang di wilayah Jawa Timur. Dalam rangka penentuan daya dukung dan daya tampung lingkungan di Jawa Timur, maka perlu dilakukan kajian awal mengenai kriteriakriterai penentu yang relevan dalam mengukur tingkat daya dukung dan daya tampung lingkungan di Jawa Timur. Terkait hal tersebut, pertanyaan dalam penelitian ini adalah: "kriteria-kriteria apa yang relevan dalam menentukan daya dukung dan daya tampung lingkungan di Jawa Timur?"

\section{METODE}

\section{II.1 Metode Pengumpulan Data}

Dalam melakukan pengumpulan data, dilakukan melalui survey primer. Metode yang dilakukan adalah dengan cara wawancara mendala (depth interview) ke beberapa stakeholder kunci yang merupakan pakar di bidang pembangunan dan lingkungan hidup. Untuk mnegetahui stakeholders kunci dalam penelitian ini, maka dilakukan analisa stakeholders yang memuat 3 kelompok, yakni pemerintah, LSM, dan akademisi. Hasil analisa stakeholders tersebut menghasilkan stakeholders kunci sebagai berikut :

- Pemerintah (Dinas Perikanan dan Kelautan, Dinas ESDM, Bappeprov, BLH Provinsi Jawa Timur) 
- $\quad$ LSM (Tunas Hijau dan Walhi)

- Akademisi (Dosen sosiologi UNAIR, dosen teknik lingkungan ITS, dan dosen ekonomi pembangunan)

\section{II.2 Metode Analisis}

Metode analisis yang digunakan dalam penentuan indikator daya tampung lingkungan binaan dan sosial ini adalah metode analisa delphi. Metode delphi ini digunakan dengan maksud untuk memperoleh kesepakatakan stakeholders mengenai indikator-indikator penentu daya tampung lingkungan binaan dan sosial yang relevan bagi wilayah Jawa Timur. Indikator yang dikonfirmasi pada analisa delphi tersebut merupakan indikator yang didapatkan dari hasil analisa deskriptif kualitatif. Artinya, indikator tersebut dihasilkan dari kajian literatur yang dibenturkan dengan permasalahan yang dihadapi pada lokasi studi.

\section{HASIL}

\section{III.1 Daya Tampung Lingkungan}

Binaan di Jawa Timur

Secara teoritis, daya tampung lingkungan binaan adalah kemampuan lahan untuk mendukung jumlah populasi yang ada \{1). Berdasarkan hasil analisa deskripif kualitatif, daya tampung lingkungan binaan didefinisikan oleh beberapa pakar menjadi beberapa indikator, yakni ketersediaan lahan, sumberdaya air, transportasi, dan kualitas lingkungan $\{2\}$ $\{15\}$. Bila dilihat dari permasalahan yang akan diselesaikan dengan penelitian ini, indikator tersebut dijabarkan menjadi beberapa variabel. Indikator ketersediaan lahan dijelaskan dengan variabel luas lahan pertanian, perikanan, peternakan, hutan, terbangun, dan lahan yang dibutuhkan untuk mengahsilkan per1000 PDRB. Indikator aspek sumberdaya air dijelaskan dengan variabel ketersediaan debit air bersih perkapita dan konsumsi air bersih perkapita. Indikator aspek transportasi dijelaskan dengan variabel panjang jalan perkapita dan jumlah bus / angkutan umum per 10.000 penduduk. Sedangkan indikator aspek kualitas lingkungan dijelaskan dengan variabel luas lahan terbuka, ratarata koefisien dasar hijua per persil bangunan (greenGDP), volume limbah industri cair yang berhasil diolah, dan volume emisi $\mathrm{SO}_{2}$ dari kegiatan industri.

Dari hasil analisa deskriptif kualitatif tersebut dijadikan masukan dalam pembuatan kuisioner analisis delphi. Berikut ini adalah hasil analisa delphi terkiat daya tamping lingkungan binaan di Jawa Timur :

Tabel 1. Hasil Analisa Delphi Indikator Daya Tampung Lingkungan Binaan di Jawa Timur

\begin{tabular}{|c|c|c|c|c|}
\hline \multirow{2}{*}{$\begin{array}{c}\text { Pak } \\
\text { ar }\end{array}$} & \multicolumn{4}{|c|}{ Indikator Daya Tampung Lingkungan Binaan } \\
\cline { 2 - 5 } & $\begin{array}{c}\text { Ketersedi } \\
\text { aan lahan }\end{array}$ & $\begin{array}{c}\text { Ketersedi } \\
\text { aan } \\
\text { sumberd } \\
\text { aya air }\end{array}$ & $\begin{array}{c}\text { Transpor } \\
\text { tasi }\end{array}$ & $\begin{array}{c}\text { Kualita } \\
\text { s } \\
\text { lingkun } \\
\text { gan }\end{array}$ \\
\hline P1 & S & S & S & S \\
\hline P2 & S & S & S & S \\
\hline P3 & S & S & S & S \\
\hline P4 & S & S & S & S \\
\hline P5 & S & S & TS & S \\
\hline P6 & S & S & S & S \\
\hline P7 & S & S & S & S \\
\hline P8 & S & S & S & S \\
\hline P9 & S & S & S & S \\
\hline
\end{tabular}

Keterangan :

$\begin{array}{lll}\text { P1 } & : & \text { LSM Tunas Hijau } \\ \text { P2 } & : & \text { LSM Walhi } \\ \text { P3 } & : & \text { Dinas Perikanan dan }\end{array}$

Kelautan Provinsi Jawa Timur

P4 : Dinas ESDM Provinsi Jawa Timur

$\begin{array}{lll}\text { P5 } & : & \text { Bappeprov Jawa Timur } \\ \text { P6 } & : & \text { Pakar Sosial (Dosen }\end{array}$

Sosiologi UNAIR)

P7 : Pakar Lingkungan (Dosen

Teknik Lingkungan ITS) 
P8 : Pakar Ekonomi (Dosen

Ekonomi Pembangunan)

P9 : BLH Provinsi Jawa Timur

S : Setuju

TS : $\quad$ Tidak Setuju

Berdasarkan hasil pengisian kuisioner analisa deplhi, indikator yang sepenuhnya disepakati oleh stakeholders adalah :

- Indikator ketersediaan lahan

Permintaan akan lahan semakin tahun semakin meningkat di Provinsi Jawa Timur. Seiirng meningkatnya pertumbuhan ekonomi di Jawa Timur,, maka terjadi kenaikan demand terhadap lahan untuk pembangunan berbagai jenis kegiatan. Adanya kenaikan demnad tersebut pastinya mempengaruhi ketersediaan (supply) lahan di Provinsi Jawa Timur. Dalam kaitannya dengan daya tampung lingkungan binaan, luasan lahan yang dapat dijadikan ukuran untuk melihat sejauh mana daya tampung lingkungan binaan pada suatu wilayah adalah luas lahan pertanian, perikanan, peternakan, hutan, terbangun, dan lahan yang dibutuhkan untuk menghasilkan per1000 PDRB. Secara garis besar luas lahan yang dimaksud menunjukkan luas lahan yang dapat menampung aktivitas sosial-ekonomi masyarakat. Dengan semakin banyaknya luasan lahan di Jawa Timur, maka daya tampung lingkungan binaan dianggap masih tinggi (mampu mendukung jumlah populasi yang ada).

- Indikator ketersediaan sumberdaya air

Indikator ini dapa dikatakan menjadi indikator utama dalam mengukur daya tampung lingkungan binaan. Hal tersebut dikarenakan aktivitas manusia tidak dapat lepas dari keberadaan sumberdaya air. Air merupakan kebutuhan dasar manusia, baik untuk dikonsumsi maupun untuk mengairi sawah. Sebagai kebutuhan yang vital, ketersediaan sumberdaya air harus bersifat kontinu dari segi kuantitas dan juga layak dalam segi kualitasnya. Dalam menjelaskan indikator ketersediaan sumberdaya air di Provinsi Jawa Timur dapat dilihat dari beberapa hal, yakni ketersediaan debit air bersih perkapita dan konsumsi air bersih perkapita. Selain itu, salah satu stakeholders mengusulkan penambahan variabel yang mampu menjelaskan indikator ketersediaan sumberdaya air, yakni variabel air permukaan. Variabel air permukaan yang dimaksud adalah ketersediaan air permukaan pada setiap golongan air. Terdapat 3 macam golongan air, yaitu golongan A yang dapat digunakan untuk minum (tanpa harus diolah terlebih dahulu); golongan B dapat digunakan untuk minum (melalui proses pengolahan terlebih dahulu sebelum dapat diminum); dan golongan $\mathrm{C}$ yang digunakan untuk perikanan, pengairan irigasi, dan sebagainya.

Dengan semakin banyaknya ketersediaan sumberdaya air, baik dari segi debit, keberadaan sir permukaan dengan golongan yang tinggi, dan konsumsi air bersih perkapita dapat terlayani dengan baik, maka daya tampung lingkungan binaan pada Provinsi Jawa Timur akan semakin tinggi (mampu mendukung jumlah populasi yang ada).

- Indikator aspek kualitas lingkungan Berdasarkan hasil analisa deskriptif kualitatif, indikator aspek kualitas lingkungan dapat dijelaskan oleh variabel luas lahan terbuka, ratarata koefisien dasar hijau perpersik bangunan (green GDP), volume 
limbah industri cair yang berhasil diolah, dan volume emisi $\mathrm{SO}_{2}$ dari kegiatan industri. Secara keseluruhan, stakeholders yang menjadi responden dalam penelitian ini setuju bahwa kondisi kualitas lingkungan di Provinsi Jawa Timur dapat menggambarkan daya tampung lingkungan binaan. Didalam Provinsi Jawa Timur masih terdapat kawasan perdesaan. Kualitas lingkungan di kawasan perdesaan pasti akan berbeda dengan kawasan perkotaan dan hal tersebut pasti mempengaruhi daya tampung lingkungan binaan di kawasan tersebut. Kawasan perdesaan yang masih memiliki luasan lahan terbuka yang tinggi dan rata-rata $\mathrm{KDH}$ yang tinggi pula akan memiliki nilai daya tampung lingkungan binaan yang lebih tinggi dibanding daerah perkotaan. Selain itu, kawasan perdesaan yang masih didominasi oleh kegiatan pertanian, memiliki volume limbah industri dan emisi $\mathrm{SO}_{2}$ yang rendah.

Selain variabel tersebut, aspek kualitas lingkungan juga dapat melihat keberadaan limbah rumah tangga. Sejauh ini, semua kota / kabupaten masih membuang limbah rumah tangga pada saluran drainase yang pada akhirnya mencermari sungai. Semakin tingginya percemaran pada suatu wilayah, maka daya tampung lingkungan binaannya akan semakin berkurang.

Daya tampung lingkungan binaan Jawa Timur berdasarkan hasil analisa deskriptif kualitatif (kajian teori yang sesuai permasalahan yang ada) menghasilkan 4 (empat) indikator daya tampung lingkungan binaan. Akan tetapi pada analisa delphi, ternyata terdapat 1 indikator yang tidak disepakati oleh 1(satu) responden, yakni indikator aspek transportasi. Stakeholder tersebut beranggapan bahwa aspek transportasi (panjang jalan perkapita, jumlah bus / angkutan umum per 10.000 penduduk) merupakan aspek eksernalitas yang timbul dari aktivitas manusia sehingga apapun perubahan dari variabel-variabel yang menjelaskan aspek tersebut tidak akan mempengaruhi daya tampung lingkungan binaan di Provinsi Jawa Timur. Sejatinya, pendapat dari stakeholders lain mengenai kaitan transportasi dengan aktivitas manusia sama dengan pendapat 1 (satu) stakeholder yang tidak setuju tersebut, akan tetapi stakeholders lain beranggapan bahwa dengan semakin meningkatkanya aspek transportasi maka akan meningkatkan emisi, pergerakan orang, barang, dan jasa sehingga daya tampung lingkungan binaan akan semakin menurun.

Adanya kondisi tersebut sebaiknya dikonfirmasi kembali (proses iterasi) pada stakeholders yang bersangkutan sehingga hasilnya dapat diambil kesimpulan untuk mengambil kesepakatan indikator daya tampung lingkungan binaan, utamanya dalam indikator aspek transportasi.

\section{III.2 Daya Tampung Lingkungan Sosial di Jawa Timur}

Daya tampung lingkungan sosial erat kaitannya dengan pola produksi dan konsumsi manusia $\{1\}$. Berdasarkan hasil kajian teoritis yang menggunakan metode analisa deksriptif kualitatif, daya tamping lingkungan sosial di Provinsi Jawa Timur dapat tergambarkan dengan indikator kependudukan, gaya hidup (life style), tingkat konsumsi penduduk, dan kondisi sosial-ekonomi masyarakatnya. Setiap indikator tersebut dijelaskan oleh variabel yang berbeda-beda. Indikator kependudukan dijelaskan oleh variabel jumlah penduduk, pertumbuhan penduduk, jenis kelamin, umur, kepadatan penduduk, dan tingkat pendidikan masyarakat. Indikator gaya hidup dijelaskan dengan variabel jenis kegiatan (aktivitas manusia) dan hubungan antar masyarakat. Indikator tingkat konsumsi penduduk dijelaskan dengan variabel tingkat konsumsu bahan makanan dan tingkat konsumsi energy. 
Sedangkan indikator kondisi sosial ekonomi masyarakat dijelaskan dengan variabel tingkat pengeluaran konsumsi masyarakat, tingkat kemiskinan penduduk, dan jenis pekerjaan penduduk $\{2\}-\{15\}$.

Hasil indikator dan variabel yang telah dihasilkan pada tahap analisa sebelumnya, diuji kembali denganmenggunakananalisa delphi, yang bertujuan untuk mendapatkan kesepakatan dengan stakeholders yang telah dipilih. Berikut ini adalah hasil analisa delphi indikator daya tamping lingkungan binaan di Jawa Timur :

Tabel 2. Hasil Analisa Delphi Indikator Daya Tampung Lingkungan Binaan di

\begin{tabular}{|c|c|c|c|c|}
\hline \multirow[b]{3}{*}{$\begin{array}{c}\text { Paka } \\
\text { r }\end{array}$} & \multicolumn{4}{|c|}{ Jawa Timur } \\
\hline & Indikator Da & Tamp & g Lingku & an Binaan \\
\hline & $\begin{array}{c}\text { Kependuduk } \\
\text { an }\end{array}$ & $\begin{array}{c}\text { Gaya } \\
\text { Hidu } \\
\text { p }\end{array}$ & $\begin{array}{c}\text { Tingkat } \\
\text { Konsum } \\
\text { si } \\
\text { Pendudu } \\
\text { k }\end{array}$ & $\begin{array}{c}\text { Sosial - } \\
\text { Ekonomi } \\
\text { Masyarak } \\
\text { at }\end{array}$ \\
\hline P1 & $\mathrm{S}$ & $\mathrm{S}$ & $\mathrm{S}$ & $\mathrm{S}$ \\
\hline $\mathrm{P} 2$ & $S$ & $S$ & $S$ & $\mathrm{~S}$ \\
\hline P3 & TS & $\mathrm{S}$ & $\mathrm{S}$ & TS \\
\hline $\mathrm{P} 4$ & $\mathrm{~S}$ & $\mathrm{~S}$ & $\mathrm{~S}$ & $\mathrm{~S}$ \\
\hline P5 & $S$ & $S$ & $S$ & $S$ \\
\hline P6 & $S$ & $\bar{S}$ & $S$ & $\bar{S}$ \\
\hline P7 & $\mathrm{S}$ & $\mathrm{S}$ & $\mathrm{S}$ & $\mathrm{S}$ \\
\hline P8 & $\mathrm{S}$ & $\mathrm{S}$ & $\mathrm{S}$ & $\mathrm{S}$ \\
\hline P9 & $\mathrm{S}$ & $\mathrm{S}$ & $\mathrm{S}$ & $\mathrm{S}$ \\
\hline
\end{tabular}

Keterangan :
P1 :
LSM Tunas Hijau
P2 : LSM Walhi
P3 : Dinas Perikanan dan

Kelautan Provinsi Jawa Timur

P4 : Dinas ESDM Provinsi Jawa

Timur

$\begin{array}{lll}\text { P5 } & \text { : } & \text { Bappeprov Jawa Timur } \\ \text { P6 } & \text { : } & \text { Pakar Sosial (Dosen }\end{array}$

Sosiologi UNAIR)

P7 : Pakar Lingkungan (Dosen

Teknik Lingkungan ITS)

P8 : Pakar Ekonomi (Dosen

Ekonomi Pembangunan)

P9 : BLH Provinsi Jawa Timur

S : Setuju
TS : $\quad$ Tidak Setuju

Dari 4 (empat) indikator daya tampung lingkungan binaan yang dihasilkan dari tahapan sebelumnya, ternyata hasnya 2 (dua) indikator yang mendapatkan kesepakatan oleh semua stakeholders yang menjadi responden. Dua indikator tersebut adalah :

- Indikator gaya hidup

Gaya hidup yang dimaksud dalam indikator ini adalah jenis kegiatan yang dilakukan individu dan hubungan masyarakat. Sejatinya, gaya hidup penduduk perkotaan dan perdesaan berbeda baik dari segi jenis kegiatan yang dilakukan hingga hubungan yang terjalin memiliki keeratan yang berbeda. Selain itu, adanya perbedaan kemampuan penduduk juga mempengaruhi gaya hidup yang terbentuk.Perbedaan-perbedaan

tersebut akan menimbulkan pola produksi dan konsumsi yang berbeda pada setiap wilayah sehingga mempengaruhi daya tampung lingkungan sosial. Sejatinya, gaya hidup dari setiap individu dapat selalu terpenuhi dalam ukuran daya tampung lingkungan sosial, dengan syarat, gaya hidup tersebut berjalan seiring dengan kompetensi penduduknya. Dengan berkembangnya kompetensi penduduk, maka teknologi untuk rekayasa daya dukung dan tampung lingkungan dapat dilakukan sehingga pembangunan berkelanjutan dapat tercapai.

- Indikator tingkat konsumsi penduduk

Tingkat konsumsi penduduk, baik berupa konsumsi bahan makan maupun konsumsi energi dirasa sangat menggambarkan daya tampung lingkungan sosial. Dengan semakin tingginya tingkat konsumsi 
penduduk, makan akan berpengaruh pada persaingan dalam perolehan kebutuhannya. Semakin bersaing, maka daya tampung lingkungan sosial semakin terbatas. Karena sejatinya tingkat konsumsi penduduk ini berbanding lurus dengan pendapatan penduduk. Dalam konsumsi energi, semakin tinggi konsumsi energi, maka semakin besar ebergi yang digunakan maka semakin baik (untuk keberlanjutan)

Dua indikator selain yang dijelaskan diatas, dianggap tidak mendapatkan kesepakatan dari stakeholdersselaku responden walaupun hanya terdapat 1 responden yang menyatakan tidak setuju. Indikator tersebutadalah :

- Indikator Kependudukan

Pengaruh indikator kependudukan terhadap daya tampung sosial didefinisikan dengan beberapa variabel yaitu jumlah penduduk, jenis kelamin, umur, kepadatan penduduk, pertumbuhan penduduk. Opini dari mayoritas stakeholder menyetujui pengaruh variabel variabel tersebut mempengaruhi daya tampung suatu lingkungan. Terdapat satu stakeholder yang tidak menyetujui indikator ini yakni dari pihak dinas kelautan dan perikanan. Sakteholder tersebut beranggapan bahwa aspek kependudukan dilingkungan pesisir kurang mempengaruhi daya tampung sosial karena jumlah penduduk pesisir yang tidak terlalu padat sehingga tidak menyeram daya tampung sosial berlebih.

- Indikator sosial-ekonomi masyarakat

○ Kondisi sosial-ekonomi masyarakat yang dijelaskan dengan variabel tingkat pengeluaran konsumsi masyarakat, tingkat kemiskinan penduduk, dan jenis pekerjaan. Secara garis besar, variabel tersebut telah menggambarkan daya tamping lingkungan sosial. Akan tetapi, terdapat 1 (satu) stakeholdersyang tidak setuju bila daya tamping lingkungan sosial di nilai dengan indikator sosial-ekonomi masyarakar. Hal tersebut dikarenakan banyaknya stakeholders beranggapan dalam lingkup wilayah pesisir, indikator ini tidak dapat menggambarkan daya tamping lingkungan sosial di Provinsi Jawa Timur. Sejatinya, indikator sosial-ekonomi masyarakat sangat mempengaruhi gaya hidup dan tingkat konsumsi penduduk.

\section{KESIMPULAN}

Berdasarkan hasil analisa dan pembahasan yang telah dilakukan pada penelitian ini, maka dapat disimpulkan bahwa:

1. Indikator daya tampung lingkungan binaan di Jawa Timur berdasarkan kesepakatan stakeholders adalah (1) indikator ketersediaan lahan, (2) ketersediaan sumberdaya air, (3) aspek kualitas lingkungan.

2. Indikator ketersediaan lahan dapat dijelaskan dengan melihat variabel luas lahan pertanian, perikanan, peternakan, hutan, terbangun, dan lahan yang dibutuhkan untuk menghasilkan per1000 PDRB. Dengan semakin luas lahan yang dapat dimanfaatkan untuk memenuhi kebutuhan aktivitas penduduk, maka daya tampung lingkungan binaan dianggap tinggi.

3. Ketersediaan sumberdaya air dijelaskan dengan variabel ketersediaan debit air bersih, 
konsumsi air bersih perkapita, dan adanya air permukaan yang dapat dimanfaatkan. Semakin tinggi tingkat ketersediaan sumberdaya air, maka semkain tinggi daya tampung lingkungan binaannya.

4. Aspek kualitas lingkungan yang dijelaskan dengan luasan lahan terbuka, rata-rata $\mathrm{KDH}$, volume limbah industri cair yang berhasil diolah, volume emisi $\mathrm{SO}_{2}$, dan besaran limbah rumah tangga. Semakin luas lahan terbuka dan semakin besar $\mathrm{KDH}$, maka semakin tinggi daya tampung lingkungan binaan. Sedangkan bila semakin rendah volume limbah industri, limbah rumah tangga, dan gas $\mathrm{SO}_{2}$ yang dihasilkan, maka semakin tinggi daya tampung lingkungan binaannya.

5. Indikator daya tampung lingkungan sosial di Jawa Timur berdasarkan kesepatakan stakeholders adalah (1) indikator gaya hidup, dan (2) indikator konsumsi penduduk.

6. Indikator gaya hidup yang dijelaskan dengan jenis kegiatan dan hubungan antar masyarakat dianggap dapat menggambarkan besar daya tampung lingkungan sosial pada suatu wilayah

7. Konsumsi penduduk baik berupa bahan makanan maupun energi akan mempengaruhi besaran daya tampung lingkungan suatu wilayah. Semakin tinggi tingkat konsumsi maka semakin terjadi persaingan, yanga rtinya daya tampung lingkungan sosial semakin terbatas.

\section{DAFTAR PUSTAKA}

[1] Daily, Gretchen C dan P.R Ehrlich [1992], Population, Sustainability, and Earth's Carrying Capacity, American Institute of Biological Sciences (Nov., 1992), pp. 761-771

[2] D. W. Schindler [1996], The
Environment, Carrying Capacity and Economic Growth, Ecological Applications, Vol. 6, No. 1 (Feb., 1996), pp. 17-19

[3] Fiala, Nathan [2008], Measuring sustainability: Why the ecological footprint is bad economics and bad environmental science, Ecological Economics, Vol.76, pp.519-525

[4] Ian Moffatt [2000], Ecological footprints and sustainable development, Ecological Economics, Volume 32 (2000), 359-362.

[5] Jonathan M Harris, Scott Kennedy [1999], Carrying capacity in agriculture: global and regional issues, Ecological Economics, Volume 29, Issue 3, June 1999, Pages 443-461

[6] Kyushik Oh, Yeunwoo Jeong, Dongkun Lee, Wangkey Lee, Jaeyong Choi [2005] Determining development density using the Urban Carrying Capacity Assessment System, Landscape and Urban Planning, Volume 73, Issue 1, 15 August 2005, Pages 1-15.

[7] Lawn, Philip [2006], Sustainable Development Indicators in Ecological Economics, Edward Elgar, UK

[8] Mark Sagoff [1995], Carrying Capacity and Ecological Economics, BioScience, Vol. 45, No. 9 (Oct., 1995), pp. 610620.

[9] Murray Lane [2010], The carrying capacity imperative: Assessing regional carrying capacity methodologies for sustainable land-use planning, Land Use Policy, Volume 27, Issue 4, October 2010, Pages 1038-1045.

[10] Robert G. Bailey. [2002], Ecoregionbased design for sustainability, Springer-Verlag, New York

[11] Rees, William and Mathis Wackernagel [1996], Urban Ecological Footprints: Why Cities Cannot Be Sustainable And Why They Are A Key To Sustainability, Elsevier Science Inc., New York

[12] Shu-Li Huang, Chun-Sheng Chen [1990], A system model to analyse 
environmental carrying capacity for managing urban growth of the Taipei metropolitan region, Journal of Environmental Management, Volume 31, Issue 1, July 1990, Pages 47-60

[13] Sven E. Jørgensen, Fu-Liu Xu, and Robert Costanza [2010], Handbook of Ecological Indicators for Assessment of Ecosystem Health, Second Edition, CRC Press, London
[14] William E. Rees [1996], Revisiting carrying capacity: Area-based indicators of sustainability, Population and Environment, Volume 17, Number 3, Pages 195- 215

[15] Xu, Linyu and Xiaodong Xie [2012], Theoretic Research on the Relevant Concepts of Urban Ecosystem Carrying Capacity, Procedia Environmental Sciences, Vol.13, pp. $863-872$ 